\title{
A FOTOGRAFIA EM ZERO HORA E ZEROHORA.COM: ESTRATÉGIAS DE APROPRIAÇÃO DE IMAGENS NAS EDIÇÕES EM SUPORTE IMPRESSO E DIGITAL
}

\author{
THE PHOTOGRAPH IN ZERO HOUR AND ZEROHORA.COM: \\ STRATEGIES OF APPROPRIATION OF IMAGES IN THE PRINTED AND \\ DIGITAL EDITIONS \\ LA FOTOGRAFÍA EN ZERO HORA Y ZEROHORA.COM: ESTRATEGIAS \\ DE APROPIACIÓN DE IMÁGENES EN LAS EDICIONES EN SOPORTE \\ IMPRESO Y DIGITAL
}

\begin{abstract}
Ana Gruszynski
Professora do Programa de Pós-Graduação em Comunicação e Informação da Universidade Federal do Rio Grande do Sul (PPGCOM/UFRGS). Pesquisadora do CNPq. anagru@gmail.com

Cristiane Lindemann

Doutoranda do Programa de Pós-Graduação em Comunicação e Informação da Universidade Federal do Rio Grande do Sul (PPGCOM/UFRGS). cristiane_lindemann@yahoo.com.br
\end{abstract}

\begin{abstract}
Resumo
$\mathrm{O}$ artigo apresenta um estudo exploratório que investiga a autoria das fotografias e o lugar de sua inserção em reportagens do jornal Zero Hora em suas edições impressa e digital (zerohora.com). Por meio da análise de conteúdo, verificamos o espaço que estas imagens ocupam na narrativa e sua articulação com os outros elementos editoriais, comparando seu modo de apropriação nos dois suportes. O corpus é constituído de cinco reportagens da Zero Hora e a cobertura a elas relacionada tematicamente veiculada nas mesmas datas no site zerohora.com que somaram 106 matérias. Os dados mostram que das 217 fotos diferentes que apareceram no online, apenas 6\% foram publicadas também no impresso - o que evidencia a diversidade no material fotográfico conforme muda o suporte. Além disso, apenas 12\% das 106 matérias do site zerohora.com não possuem fotos. Observou-se também a adoção de funcionalidades características da rede como links para bancos de dados e inserção dos internautas no processo produtivo. As iniciativas
\end{abstract}

\section{Esta obra está licenciada sob uma Licença Creative Commons}


avaliadas revelam mudanças e tensões que demonstram em um caso singular experiências editoriais que delineiam modos de reconfiguração de processos e produto jornalísticos.

Palavras-chave: Fotografia. Webjornalismo. Jornalismo impresso. zerohora.com. Zero Hora.

\begin{abstract}
The article presents an exploratory study that investigates the authorship of the photographs and its place of insertion in the newspaper Zero Hora reports in its print and digital editions (zerohora.com). Through content analysis, we examined the space that these images occupy in the narrative and its articulation with the other editorial elements, comparing their mode of appropriation in the two media. The corpus is composed of five stories of the Zero Hour and cover the related thematically conveyed on the same dates on the site zerohora.com that totaled 106 materials. The data show that of the 217 different pictures that appeared in online, only $6 \%$ were published also in printed - which highlight the diversity of photographic material as changes the support. In addition, only $12 \%$ of 106 subjects from the website zerohora.com does not have photos. We also noted the adoption of features characteristics of the network and links to databases, and integration of Internet users in the production process. The initiatives evaluated show changes and tensions that reveals in a unique case editorial experiences that describe modes of reconfiguration of journalism processes and products.
\end{abstract}

Keywords: photograph. Web journalism. Printed press. zerohora.com. Zero Hora.

\title{
Resumen
}

El artículo presenta un estudio exploratorio que investiga la autoría de las fotografías y el lugar de su inserción en los informes periódicos Zero Hora en su edición impresa y digital (zerohora.com). Por medio de análisis de contenido, hemos examinado el espacio que ocupan estas imágenes en la narrativa y su articulación con los otros elementos editoriales, comparando su modo de apropiación en los dos soportes. El corpus se compone de cinco informes de Zero Hora y la cobertura relacionada con las mismas temáticas y fechas en el sitio zerohora.com, un total de 106 historias. Los datos muestran que de 217 imágenes diferentes que aparecieron online, sólo el $6 \%$ también fueron publicados en forma impresa - que pone de relieve la diversidad de material fotográfico a medida que cambia el soporte. Por otra parte, sólo $12 \%$ de los 102 informes del sitio zerohora.com no tienen fotos. Hubo también la adopción de características de la red como enlaces a bases de datos y características de integración de los usuarios de Internet en el proceso de producción. Las iniciativas demuestran cambios y las tensiones presentadas en un caso único experimentos editoriales que delinean modos de reconfiguración de procesos y de productos periodísticos.

Palabras clave: Fotografía. Web journalism. Periodismo impreso. zerohora.com. Zero Hora 


\section{INTRODUÇÃO}

O jornalismo é uma prática social que coloca em circulação o conhecimento através de diferentes meios. Dos jornais impressos até as mais recentes plataformas de leitura baseadas em tecnologias digitais conectadas em rede, vamos perceber, como indica Pavlik (2001), que as transformações - ainda em curso - passam pela natureza do conteúdo, do trabalho jornalístico, da estrutura das redações e das empresas jornalísticas, bem como pelas relações entre organizações de notícias, jornalistas e seus diferentes públicos. Nesse sentido, são muitos os desafios impostos aos profissionais da área, que passam a lidar com uma lógica comunicacional em significativa mutação, como fica evidente ao observarmos a trajetória dos jornais na web.

Inicialmente os sites jornalísticos eram bastante simples e pouco exploravam características específicas da plataforma digital - hipertextualidade, interatividade, multimidialidade, customização, memória e instantaneidade (PALÁCIOS, 2002) —, limitando-se a transpor o conteúdo da edição impressa para a versão da web. Ao final do século XX, o acesso à Internet ainda era lento, de modo que as imagens digitalizadas eram pesadas para serem carregadas nos computadores domésticos, não havia softwares específicos para publicação desta natureza, e os profissionais tinham pouca familiaridade com os recursos digitais. Os avanços tecnológicos e sua apropriação pelas equipes de trabalho possibilitaram a evolução do jornalismo digital, conforme se ampliaram as experiências vinculadas às potencialidades do novo suporte. (BARBOSA, 2004; MACHADO, 2004; MIELNICZUK; 2003; PAVLIK, 2001).

Segundo Machado et. al. (2007, p.117), à medida que o ciberespaço se desenvolve, o jornalismo digital se altera, passando pelo reaproveitamento dos conteúdos dos meios convencionais (1995-1997); pela metáfora dos meios convencionais (1997-1999); pelo lançamento de produtos adaptados ao novo meio (1999-2000); para chegar ao estágio atual em que temos o desenvolvimento de produtos articulados em torno de bases de dados complexas e de canais que possibilitam a participação do público na produção de conteúdo (2002 em diante). Tais modelos, indicam os autores, são complementares, e podem até coexistir em um mesmo período, destacando-se a passagem para um novo tipo de modelo que se torna o predominante. (STRELOW et. al., 2010)

Considerando este contexto, estabelecemos como foco do presente artigo a fotografia. 
Apropriando-nos de uma colocação de Santaella (2006, p.199), partimos do princípio de que "ao aumento da complexidade e precisão do aparato tecnológico corresponde o aumento da facilidade de seu uso e a consequente trivialização"1. Levamos em conta que uma vez que os profissionais dominam as técnicas digitais de produção e publicação, conformam produtos jornalísticos que assumem forma material também por meio do design. $\mathrm{O}$ termo material é tomado aqui no sentido de que mesmo o acesso às informações constituídas numericamente (bits), para serem acessadas pelos leitores/espectadores/interagentes, necessitam de sua apreensão pelos canais sensíveis. Portanto, no papel, na tela, no espaço em que se visualizam formas e se disseminam sons, temos opções de dados multimodais que se articulam segundo estratégias de design.

Como um elemento que compõe a narrativa jornalística, a fotografia - imagem visual fixa - assume "uma materialidade marcadamente simbólica, não está ali apenas para ilustrar. [...] Acompanhando textos [...], a foto torna-se argumento do jornalista, complementando a veracidade sobre o que ali se escreve, ajudando a comprovar o que foi dito." (VAZ, 2006, p.9-10) Ao realizarmos um estudo exploratório que investiga a autoria das imagens fotográficas e o lugar de sua inserção em reportagens do jornal Zero Hora em suas edições impressa e digital (zerohora.com ${ }^{2}$ ), analisamos o espaço que ocupa na narrativa e sua articulação com os outros elementos editoriais, comparando o modo de apropriação das imagens das duas edições. O corpus analisado compreendeu as matérias do ano de 2010 dos dias 4 e 5 de agosto sobre a neve no Sul do país; do dia 9 de agosto, referente ao escândalo das diárias dos vereadores de Triunfo-RS; e dos dias 18 e 19 de agosto, que tratam, respectivamente, das coberturas pré e pós-jogo final do campeonato Libertadores da América (Inter x Chivas).

O estudo está vinculado às pesquisas realizadas no Laboratório Eletrônico de Arte \& Design (LEAD) da Faculdade de Biblioteconomia e Comunicação da Universidade Federal do Rio Grande do Sul (Fabico/UFRGS) ligado à Linha de Pesquisa em Jornalismo e Processos Editoriais do Programa de Pós-graduação de Comunicação e Informação (PPGCOM) e contam com o apoio da Capes e CNPq. Por meio de diferentes objetos e perspectivas, estas vem

\footnotetext{
${ }^{1}$ A autora faz esta colocação referindo-se ao avanço das tecnologias que permitem a captura, publicação e distribuição da fotografia, como câmeras digitais, celulares e Internet. Acreditamos, no entanto, que esta consideração pode se ampliar a outros aparatos tecnológicos que facilitam a produção, publicação e distribuição de conteúdos jornalísticos na web ou fora dela.

${ }^{2}$ http://www.zerohora.com.
} 
investigando as mudanças em andamento nos processos e nos produtos editoriais tendo em vista as tecnologias digitais e a Internet, as múltiplas plataformas de leitura e a configuração material dos conteúdos.

\section{A FOTOGRAFIA JORNALÍSTICA}

A fotografia propicia experiências estéticas e informativas quando utilizada no jornalismo, expandindo aquelas iniciadas com a presença das ilustrações nos periódicos. Ainda que tenha surgido na metade do século XIX, foi somente no século XX que passou a ocupar espaço, de fato, nos jornais diários - descompasso que se justifica, basicamente, por questões tecnológicas. Por meio dela se ampliaram as possibilidades descritiva e argumentativa do textual, pois o campo do visual permite estas mesmas funções, adicionadas de indicialidade, presença e testemunho (SILVA Jr.; QUEIROGA, 2010). Vinculada histórica e culturalmente à noção de credibilidade, é, enquanto traço do real, na relação de contiguidade entre signo e referente, que a fotografia encontra sua singularidade em relação às outras imagens. $O$ processo digital fotográfico, ao colocar em crise princípios teóricos ligados ao campo, evidenciou justamente esta concepção da fotografia analógica como representação do real mediante contato direto com a dimensão material (ROUILLÉ, 2009). Se o ato fotográfico na contemporaneidade não mais atesta a existência de um fato por meio da presença do referente, no campo do jornalismo a presença da fotografia como documento ainda é um valor, tensionado pela noção de verdade.

Nesse sentido, o texto é um elemento imprescindível da mensagem fotojornalística, orientando seus significados. Conforme Sousa (2002, p.76-77), entre suas principais funções estão: (1) chamar a atenção para a fotografia ou para alguns dos seus elementos; (2) complementar informativamente a imagem, inclusive devido à incapacidade que esta possui de mostrar conceitos abstratos; (3) ancorar o significado da fotografia; (4) abrir o leque de significações possíveis orientando o leitor; e (5) analisar, interpretar e/ou comentar a imagem e/ou o seu conteúdo. Para o autor, mesmo passados mais de cem anos após o começo da aparição regular da fotografia na imprensa, a conclusão que podemos tirar é a mesma: 
[...] texto e imagem não são convertíveis um ao outro e têm ambos lugar no jornalismo - possuem diferentes faculdades, impressionam de forma diferente, originam percepções diferenciadas e oferecem diferentes tipos de informação e de conhecimento (ou, pelo menos, familiarizam o observador com o observado de forma diferente). (SOUSA, 2004, p.203-204)

Sousa (2004, p.222) pondera que a televisão e os meios multimídia reduziram a autoridade social do fotojornalismo enquanto representação e figuração do mundo ${ }^{3}$, o que justifica sua sugestão de que esta prática deve encontrar "novos usos sociais e novas funções". Machado (2005), por sua vez, vê o surgimento da fotografia eletrônica como chave na crise do seu caráter documental, em seu papel de "árbitro da verdade".

Vemos que as inovações tecnológicas demandam a atualização constante dos fotojornalistas a novas rotinas, táticas e estratégias profissionais de captura, processamento, seleção, edição e distribuição das imagens, exigindo também o estabelecimento de parâmetros que balizem a prática e confiram unidade ao campo. Além disso, a inserção do "cidadão comum" na produção de conteúdo jornalístico, bem como a criação de bancos de dados de imagens digitais que podem ser vinculados a diferentes reportagens online, mobilizam a revisão de parâmetros consolidados de produção e configuração dos produtos editoriais onde as fotografias circulam.

\subsection{Do impresso para a web}

Se, como vimos, os primeiros jornais se caracterizaram por serem transposições do jornal impresso e a rotina produtiva estava atrelada ao ritmo diário das redações (atualização a cada 24 horas), nas experiências pioneiras o uso de fotografias era muito reduzido, ocupando lugar secundário em relação ao texto. Para Canavilhas, isso se justifica

Devido a questões técnicas (baixa velocidade na rede e interfaces textuais), a Internet começou por distribuir os conteúdos do meio substituído - o jornal. Só mais tarde o rádio e a televisão aderiram ao novo meio, mas também nestes casos se limitaram a transpor para a Internet os conteúdos já

\footnotetext{
${ }^{3}$ A noção de fotografia como espelho da verdade está vinculada a sua história cultural, de berço positivista. A ideia norteadora do ato era: o fotógrafo esteve no local do acontecimento, testemunhou e registrou a verdade, cuja prova é o resultado final, a fotografia. Contudo, o próprio objeto - a câmera - elimina este ideal. Procedimentos óticos, químicos e técnicos influenciam na imagem a ser captada. (SOUSA, 2004)
} 
disponibilizados no seu suporte natural. [...] É um completo desperdício tentar reduzir o novo meio a um simples canal de distribuição dos conteúdos já existentes. [...] E a ser assim, a Internet, por força de poder utilizar texto, som e imagem em movimento, terá também uma linguagem própria, baseada nas potencialidades do hipertexto e construída e torno de alguns dos conteúdos produzidos nos meios existentes. (CANAVILHAS, 2001, online)

Essa linguagem própria passou a ser lapidada aos poucos. Em um segundo momento, os jornais começaram a explorar as características oferecidas pela rede inserindo links com chamadas para as notícias, o e-mail passou a ser utilizado como meio de comunicação entre jornalista e leitor e, de maneira crescente, outros recursos de hipertexto também são utilizados. A fotografia então

[...] só aparece em tamanho reduzidíssimo, denominado thumbnail (tamanho miniatura), sem links, ilustrando uma ou duas matérias mais importantes na home page do site e, por vezes, alguma matéria, também em pequenas dimensões, dentro de algum das editorias. Era comum, inclusive, alguns desses sites oferecer versões text only (somente texto, com exclusão de fotos e outras imagens). (MUNHOZ, 2007, p.9)

Segundo o autor, apesar do pequeno formato, sua presença se torna mais frequente, contendo links que permitem melhor visualização ou que remetem para uma galeria de fotos em que o leitor escolhe a resolução. O problema, à época, era a demora para carregamento das páginas atrelada à baixa qualidade/velocidade de transmissão de dados.

Já o que caracteriza um terceiro momento de apropriação tecnológica é a exploração dos potenciais específicos da web para fins jornalísticos, quando temos o uso da multimídia, da interação, opções para configuração do produto conforme o gosto do usuário e a utilização mais qualificada do hipertexto na narrativa dos fatos. Também o surgimento de softwares específicos para a produção e publicação de notícias online é significativo. Os sites passam então a apresentar outros usos da fotografia, como sequências de imagens (slideshows), conciliando sons e espaço para comentários sobre as mesmas (MIELNICZUK, 2003). "Do ponto de vista da fotografia na Web, é importante assinalar que o uso dos recursos que caracterizam essa terceira geração de sites jornalísticos só vem sendo possibilitado pela expansão da tecnologia de transmissão de dados: a banda larga" (MUNHOZ, 2007, p.12). Para Munhoz isso representa um

\footnotetext{
${ }^{4}$ Conexão de Internet com capacidade para transmitir dados em alta velocidade.
} 
divisor de águas quando se fala em fotografia no webjornalismo - o que exigiria uma outra classificação para a evolução histórica do fotojornalismo online, que não o de três gerações utilizada por alguns autores quando se trata do tema ${ }^{5}$.

Segundo Barbosa (2007) os bancos de dados marcam a transição para uma quarta geração da prática jornalística na $w e b^{6}$, quando se dá relacionamento mais próximo entre produtores e consumidores, estimulando a participação dos usuários para a criação de conteúdos; investimentos em softwares que habilitem ferramentas de publicação de conteúdos originais; uso de vídeo, áudio e de ilimitadas bases de dados; a especialização de profissionais. Para a autora,

As bases de dados são definidoras da estrutura e da organização, bem como da apresentação dos conteúdos de natureza jornalística. Elas são os elementos fundamentais na constituição de sistemas complexos para a criação, manutenção, atualização, disponibilização e circulação de produtos jornalísticos digitais dinâmicos (BARBOSA 2007, p.214).

Uma base de dados simples pode reunir a relação dos bens de uma determinada pessoa física; já bases de dados complexas, como as utilizadas pelas organizações jornalísticas, envolvem muitos tipos diferentes de dados interdependentes e inter-relacionados, incluindo textos, imagens, gráficos e objetos multimídia (som e vídeo), aumentando as proporções das necessidades de armazenamento e a complexidade dos processos de recuperação e processamento dos dados. (MACHADO, 2011, online)

A alimentação dos bancos de dados já não compreendem apenas os jornalistas ou profissionais vinculados às empresas de comunicação. Por meio dos sistemas interativos, pessoas munidas de câmeras portáteis digitais e com internet acessível por meio de aparelhos fixos, celulares ou outras tecnologias móveis, se tornam potenciais produtoras de informação durante 24h. Mudam também os modos de circulação e apresentação destas imagens, que podem ser agrupadas em galerias ou slideshows, vinculando-se a textos distintos.

Em meio a essas adaptações de produção na web, vemos a tentativa de aproveitar o

\footnotetext{
${ }^{5}$ Munhoz (2007) faz a observação e ressalta que esta análise e a possível criação de uma nova tipologia para o desenvolvimento histórico do fotojornalismo na Web rendem uma pesquisa à parte.

${ }^{6}$ Barbosa (2007) afirma que na fase atual a produção absorve diversas tecnologias digitais em suas rotinas, como arquivos de áudio gerados em IPODs, fotografias tiradas com câmeras digitais, entrevistas gravadas por telefones celulares, dentre outros. Por este motivo ela defende a utilização do termo jornalismo digital, em vez de webjornalismo. Neste trabalho, no entanto, seguiremos com o padrão já estabelecido, para manter uma coerência, condiserando que o termo não comprometerá o entendimento do mesmo.
} 
potencial da plataforma digital para disponibilizar aos internautas conteúdos diferenciados, que superem ou complementem, de alguma forma, os meios impressos. A rede oferece a possibilidade de atualização constante e em tempo real, a multimidialidade e um redimensionamento dos limites de espaço para armazenamento de materiais. É justamente o cruzamento destes aspectos que permite uma maior exploração do material fotográfico, se estabelecemos um contraponto com o impresso, onde a linha editorial, o espaço fixo nas páginas, o horário de fechamento e o setor comercial são alguns dos impeditivos para que a fotografia tenha maior visibilidade.

Segundo Munhoz (2007), na passagem do milênio, três importantes avanços técnicos na área digital impuseram mudanças na rotina do fotojornalismo: (1) a digitalização da transmissão dos negativos que aceleraram os ganhos de tempo e dinheiro, ainda que o sistema precário só permitisse enviar duas ou três fotos por dia (1995); (2) o uso de câmeras digitais quando as fotos passaram a ser transmitidas em poucos segundos direto do local do acontecimento (1998); (3) a digitalização de arquivos de grandes agências e a criação de bancos de dados integrados na Internet possibilitaram que empresas como Agence France-Presse, Associated Press e Reuters passassem a oferecer, em tempo real, fotos de acontecimentos em qualquer lugar do mundo (séc. XXI).

Portanto, o potencial técnico está à disposição e problemas como falta de qualidade das imagens ou baixa velocidade da Internet para carregá-las já não são impeditivos para que os veículos online explorem as fotografias em suas produções. "A Internet associada à funcionalidade cada vez maior de computadores, celulares, PDAs (personal digital assistant), laptops, gera um novo e dinâmico espaço de veiculação das fotografias jornalísticas, que abastecem esse mercado on-line 24 horas por dia" (MUNHOZ, 2007, p.3). O estudo exploratório apresentado na próxima seção visa verificar, ainda que de modo incipiente, como fotografias estão sendo utilizadas na narrativa jornalística, observando a cobertura de um mesmo tema nas edições impressa e online de Zero Hora, para assim discutir seus modos de apropriação em diferentes suportes.

\section{APRESENTAÇÃO, ANÁLISE E DISCUSSÃO DOS DADOS}


O jornal impresso Zero Hora ( $\mathrm{ZH})$ e sua versão online zerohora.com fazem parte da Rede Brasil Sul de Comunicação (RBS), fundada em 1957 por meio da aquisição de uma rádio, e consolidada como um conglomerado na década de 1970, quando seus proprietários adquiriram um jornal e um canal de televisão. A RBS TV é afiliada da Rede Globo desde 1971 (quando ainda denominava-se TV Gaúcha) e o grupo tem posição hegemônica no mercado de comunicação da região Sul (FONSECA, 2008), com jornais, rádios e canais de televisão nos estados do Rio Grande do Sul e Santa Catarina ${ }^{7}$.

Neste estudo exploratório, as unidades de análise são reportagens veiculadas no jornal Zero Hora e matérias sobre o mesmo tema apresentadas do site zerohora.com no mesmo dia, que foram avaliadas por meio da análise de conteúdo ${ }^{8}$. Selecionamos arbitrariamente reportagens publicadas nas páginas 4 e 5 de ZH impressa, tendo em vista que este é o espaço de destaque que o jornal abre para uma pauta, a partir do que deduzimos que nele a fotografia teria maior possibilidade de ser explorada. Além disso, por terem maior visibilidade, estas páginas geralmente abordam temas socialmente relevantes, impactantes e/ou com amplo interesse público.

Foram escolhidas cinco edições para análise (Figs. 1 a 5): 4 e 5 de agosto de 2010, cujas reportagens abordam a neve no Sul do país (foco para SC e RS); 9 de agosto de 2010, com reportagem sobre o escândalo de diárias concedidas a vereadores da cidade de Triunfo (RS); e os dias 18 e 19 de agosto de 2010, quando as matérias tiveram como tema o pré e o pós-jogo final da Copa Libertadores da América (Internacional x Chivas), respectivamente. Para cada uma destas demos um código que, posteriormente, foi utilizado na operacionalização da análise (Tab.1 $)^{9}$.

\footnotetext{
${ }^{7}$ Conforme levantamento feito por Fonseca, em 2008 o grupo possuía seis jornais diários, 25 emissoras de rádio, a maior rede de televisão regional da América Latina (17 emissoras filiadas à Rede Globo e duas emissoras de TV local - sistema TV COM), uma unidade de negócios voltada para o desenvolvimento de conteúdos multimídia (RBS Online), um site de notícias e portal (ClicRBS) um site de notícias sobre agronegócios (Agrol), uma unidade corporativa de perfil multimídia com foco no agronegócio (RBS Rural, com site, rádio e canal de TV), uma central de meteorologia, entre outros (FONSECA, 2008, p.213-215).

${ }^{8}$ Para Bardin (1977, p.42), este método consiste num "conjunto de técnicas de análise das comunicações visando obter, por procedimentos sistemáticos e objetivos de descrição do conteúdo das mensagens, indicadores (quantitativos ou não) que permitam a inferência de conhecimentos relativos às condições de produção / recepção (variáveis inferidas) destas mensagens".

${ }^{9}$ A letra "I" do código indica que a matéria foi publicada no veículo impresso.
} 

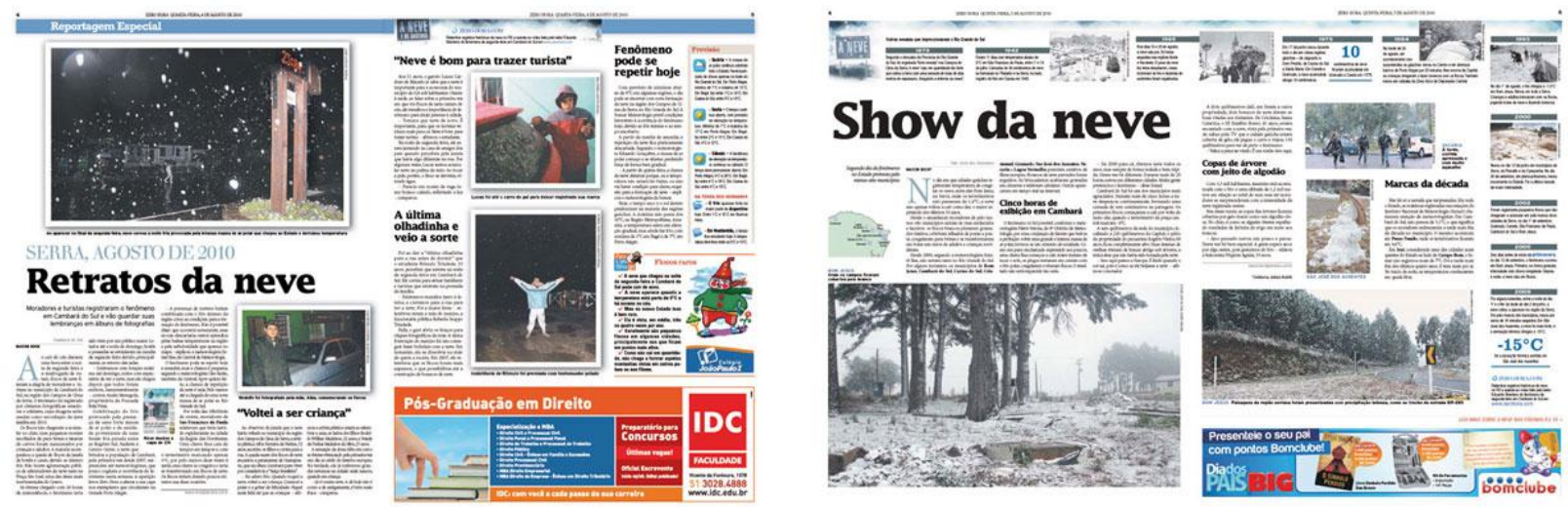

Fig. 1 - Páginas 4 e 5 de $\mathrm{ZH}$ de 4 de agosto de 2010

Fig. 2 - Páginas 4 e 5 de $\mathrm{ZH}$ de 5 de agosto de 2010

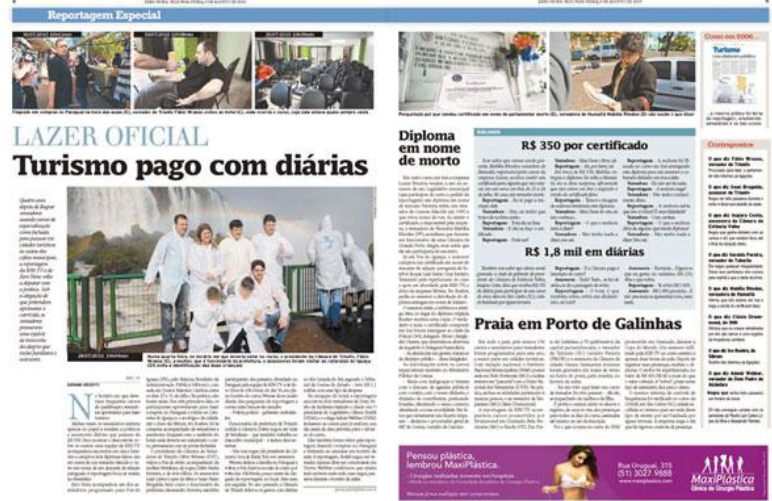

Fig. 3 - Páginas 4 e 5 de $\mathrm{ZH}$ de 9 de agosto de 2010
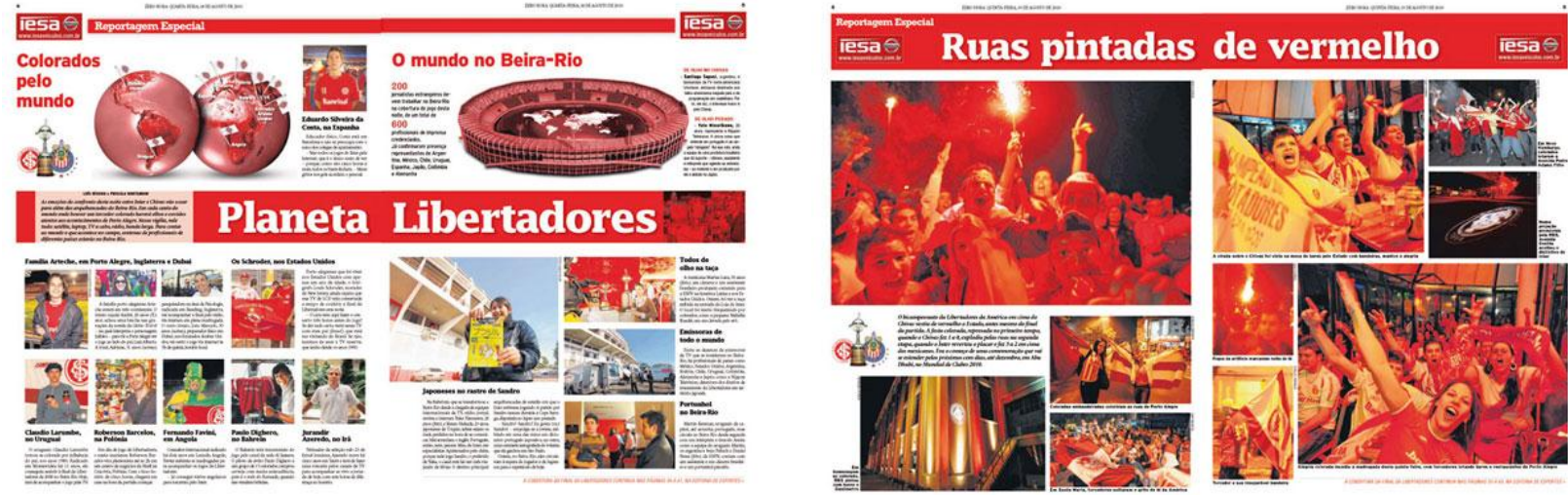

Fig. 4 - Páginas 4 e 5 de $\mathrm{ZH}$ de 18 de agosto de 2010

Fig. 5 - Páginas 4 e 5 de $\mathrm{ZH}$ de 19 de agosto de 2010

ANIMUS R. Interamericana de Comunicação Midiática, http://www.ufsm.br/revistas E-ISSN 2175-4977, v. 10, n. 20, 2011 


\begin{tabular}{c|c|l|c|}
\hline Cód. & Data & \multicolumn{1}{|c}{ Título } & Fotos \\
\hline I-A & $04 / 08 / 10$ & Retratos da neve & 4 \\
\hline I- B & $05 / 08 / 10$ & Show da neve & 9 \\
\hline I- C & $09 / 08 / 10$ & Turismo pago com diárias & 6 \\
\hline I-D & $18 / 08 / 10$ & Planeta Libertadores & 14 \\
I-E & $19 / 08 / 10$ & Ruas pintadas de vermelho & 10 \\
\hline
\end{tabular}

Tab. 1 - matérias analisadas no impresso

A partir destas reportagens, identificamos na versão online ${ }^{10}$, nessas mesmas datas, todas as matérias com temas correspondentes. A reportagem A desdobrou-se em 20, a B em 10, a C em 6, a D em 28 e a $\mathrm{E}$ em 42. Na contagem das fotos, consideramos não apenas aquelas que acompanhavam um texto, mas também as que são apresentadas por meio de links que remetem a galerias ou slideshows ${ }^{11}$.

Quanto ao formato de apresentação, no jornal impresso percebemos a presença de um diagrama (grid) que delimita a mancha gráfica, mas que é bastante variável tanto no dimensionamento de base das colunas (quatro ou cinco com medidas variáveis), como na distribuição dos elementos no espaço modulado. É possível que esta variação significativa esteja associada ao tipo de reportagem publicado nestas páginas, espaço destinado à cobertura de temas variados de impacto e relevância local. Na cobertura dos dias 4, 5 e 9 de agosto (Figs. 1 a 3), podemos observar a presença de um foto em destaque que ocupa praticamente toda a largura da mancha gráfica - o que reforça sua função estética -, e a inclusão de imagens menores de caráter mais informativo. As edições dos dias 18 e 19 de agosto (Figs. 4 e 5) apresentam um número significativo de imagens, mas sua integração na narrativa é distinta. Na Fig. 4 o texto ancora a leitura das fotos que estão presentes em tamanho reduzido, indicando um argumento de caráter prioritariamente informativo. Já na Fig. 5, as imagens ocupam praticamente toda a mancha, e por características de tamanho, cor e proximidade, revelam a força do apelo estético, assumindo um papel condizente com a emoção da vitória de um campeonato.

\footnotetext{
${ }^{10} \mathrm{O}$ objetivo deste trabalho é ver como o material fotográfico é explorado nas edições impressa e online. Por este motivo não consideramos no site zerohora.com as matérias da seção "edição impressa", que é uma reprodução literal do conteúdo em papel e está disponível apenas para assinantes.

${ }^{11}$ Slideshows também são galerias onde as fotos ficam armazenadas, porém, seu formato de apresentação é diferenciado, dispondo de botões para visualizar as fotos individualmente ou em sequência automática. Nas "galerias comuns", as imagens ficam dispostas lado a lado, em miniaturas, todas aparecendo concomitantemente no layout.
} 
O site zerohora.com segue padrões de layout/arquitetura para publicação das fotos ${ }^{12}-\mathrm{a}$ maioria das matérias é acompanhada de apenas uma, que aparece no canto direito do texto, com legenda e crédito (Fig. 6). Ao clicar nesta imagem, ela pode: 1) ser ampliada em uma nova janela; 2) remeter a um slideshow; ou 3) abrir uma nova tela com galeria de imagens. Em alguns casos, também são inseridas fotografias no meio do texto. Estas, no entanto, estão sempre soltas, sem link, legenda e ou crédito. Apenas uma das matérias com fotos no meio do texto fugiu a esta regra, registrando o crédito do fotógrafo logo abaixo das imagens (Fig. 7). Observamos ainda, em relação ao formato de apresentação, que os links que remetem aos slideshows e galerias se apresentam de duas formas: na própria foto que ilustra a matéria ou nas frases em vermelho (Fig. 8).

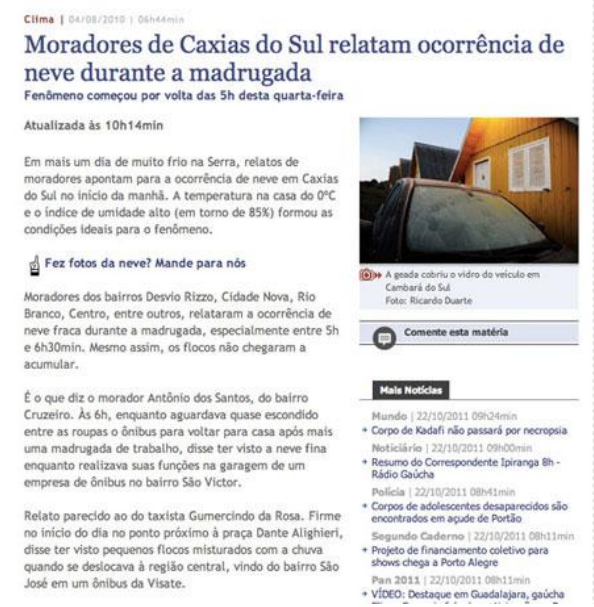

Fig. 6 - Layout que mais se repetiu no online
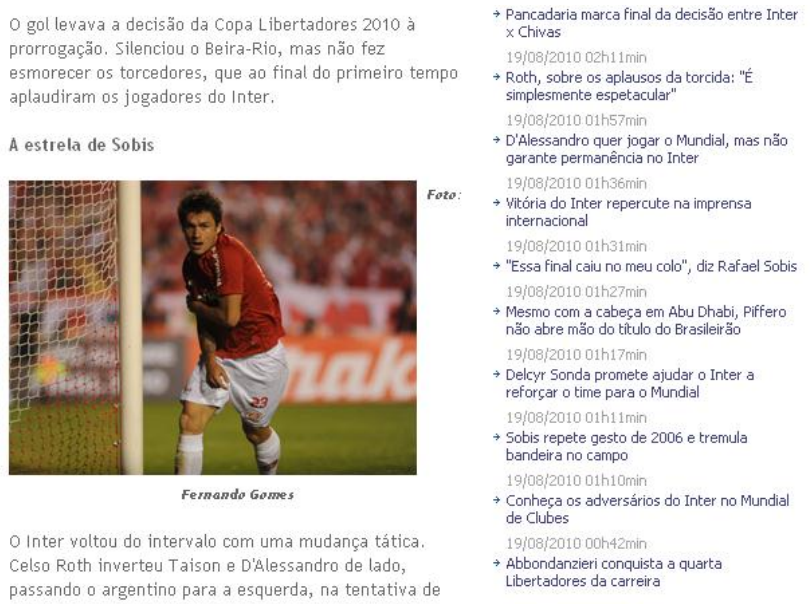

Fig. 7 - Foto no meio da matéria, com crédito e sem legenda

\footnotetext{
${ }^{12}$ No dia 6 de novembro de 2011 o site de ZH inaugurou uma nova identidade visual. Este estudo, no entanto, foi realizado antes desta data - portanto, com o design antigo.
} 


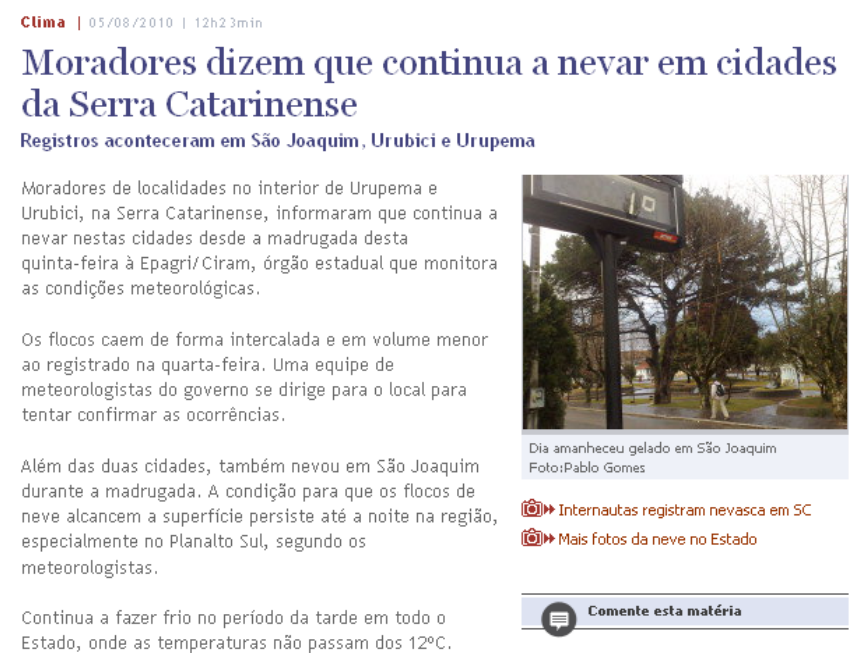

Fig. 8 - Links na foto ou nas frases em vermelho

É importante destacarmos que as fotos dos slideshows e das galerias são de boa qualidade e carregam rapidamente. Além disso, todas têm legenda e crédito - o que nos permitiu verificar uma falha no conteúdo acessado por meio do link "veja mais fotos da neve no Estado", disposto em algumas matérias relativas a cidades gaúchas. Ao clicar, o slideshow apresenta fotos do RS e de SC - o que pode ser confirmado a partir das legendas. Nestes casos, houve um descuido em relação à informação, sendo que o internauta desatento pode tê-la absorvido de maneira errônea, pensando tratar-se apenas de imagens da neve no estado gaúcho.

\subsection{Um olhar sobre a fotografia nas reportagens selecionadas}

No primeiro dia de análise (I-A) foram veiculadas 20 matérias sobre o mesmo tema na versão online. O material impresso publicou 4 fotografias ${ }^{13}$ e o online 1.176 - das quais apenas $78(6,63 \%)$ são originais ${ }^{14}$. O expressivo número total se deve à repetição de links nas matérias remetendo sempre aos mesmos slideshows ou galerias de imagens - um indício da utilização de banco de dados, característica da quarta geração de webjornalismo.

\footnotetext{
${ }^{13}$ Não contabilizamos as fotos das chamadas de capa e contracapa.

${ }^{14}$ A palavra "original" será empregada no sentido de "não repetida".
} 


\begin{tabular}{|c|c|}
\hline Matéria I-A & \\
\hline Total de matérias online .......................................... & 20 \\
\hline Total de matérias com foto & 19 \\
\hline Total de matérias sem foto & 1 \\
\hline Total de fotos no online & 1.176 \\
\hline Total de fotos originais & 78 \\
\hline Total de fotos repetidas no impresso ..................... & 1 \\
\hline
\end{tabular}

Tab. 2 - Dados em 4 de agosto

Uma comparação das fotografias nos dois suportes mostra apenas uma imagem em comum, com crédito Liane Castilhos/Especial, não ficando claro, com esta designação, se ela é ou não uma leitora-repórter ${ }^{15}$. No online (Fig. 9) esta imagem aparece em uma galeria de fotos, com registro de publicação do dia 3 de agosto - ou seja, um dia antes de ter aparecido no impresso, onde ocupou lugar de destaque na página 4, acima do título (Fig. 10).

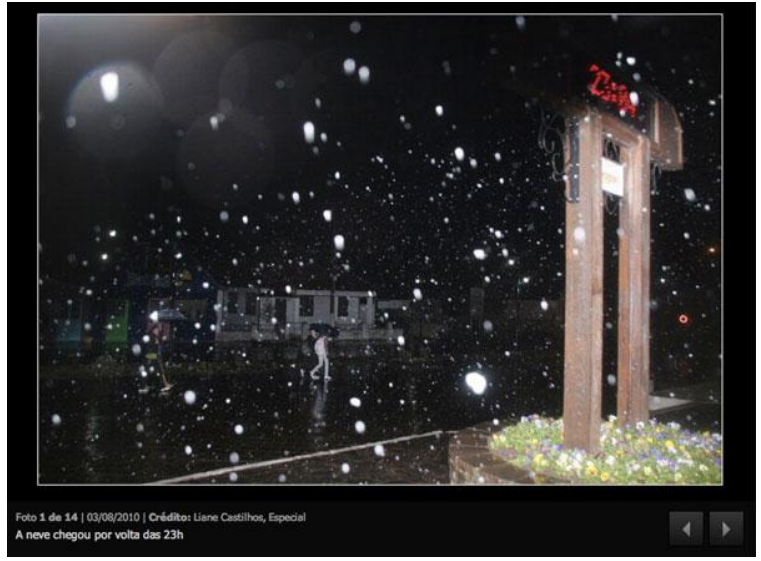

Fig. 9 - Foto publicada em galeria online

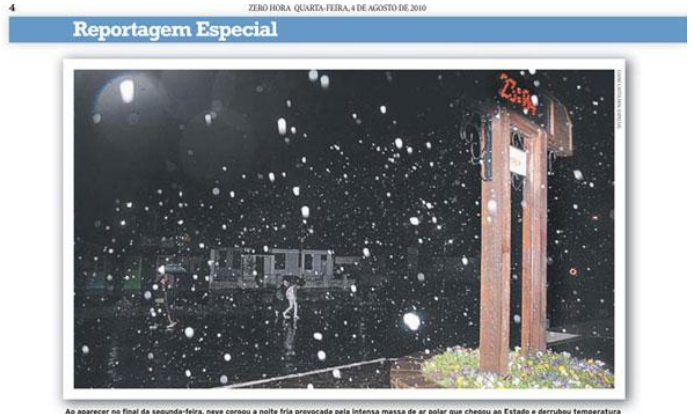

SERRA, AGOSTO DE 2010

Retratos da neve

Fig. 10 - Foto em destaque no jornal impresso

No dia 5 de agosto (I-B) foram publicadas 10 matérias sobre o tema na versão online. $\mathrm{O}$ material impresso apresentou 9 fotografias e o online 704 - das quais apenas $57(8,10 \%)$ diferenciam-se (Tab. 3).

\footnotetext{
${ }^{15}$ Leitor-repórter é um termo utilizado no jornalismo participativo quando cidadãos comuns tem a possibilidade de colaborar com a produção editorial de algum veículo, enviando texto, foto, som ou vídeo.
} 


\begin{tabular}{|c|c|}
\hline \multirow{2}{*}{\multicolumn{2}{|c|}{$\begin{array}{l}\text { Matéria I - B } \\
\text { Total de matérias online } \ldots \ldots \ldots \ldots \ldots \ldots\end{array}$}} \\
\hline & 10 \\
\hline Total de matérias com foto ............ & \\
\hline Total de matérias sem foto .. & \\
\hline & 704 \\
\hline tol & 57 \\
\hline o impresso . & \\
\hline
\end{tabular}

Tab. 3 - Dados em 5 de agosto

Comparando-se as fotografias da Zero Hora e do site zerohora.com, constamos quatro imagens em comum, sendo que estas apareceram no online já no dia anterior (4 de agosto), em um slideshow. Observamos que duas delas foram cortadas/redimensionadas para serem publicadas no impresso (Figs. 11, 12, 15 e 16). Uma foi produzida por Arthur Alexandre de Oliveira, identificado como leitor-repórter (Fig. 14) e as demais fotos são creditadas a Duclerc João da Silva/Gazeta Serrana, Leila Almeida (sendo que no impresso aparece como Leila Almeida/Divulgação) e Ricardo Duarte (Figs. 11, 13, 15), não ficando explícito se os dois últimos são leitores-repórteres.
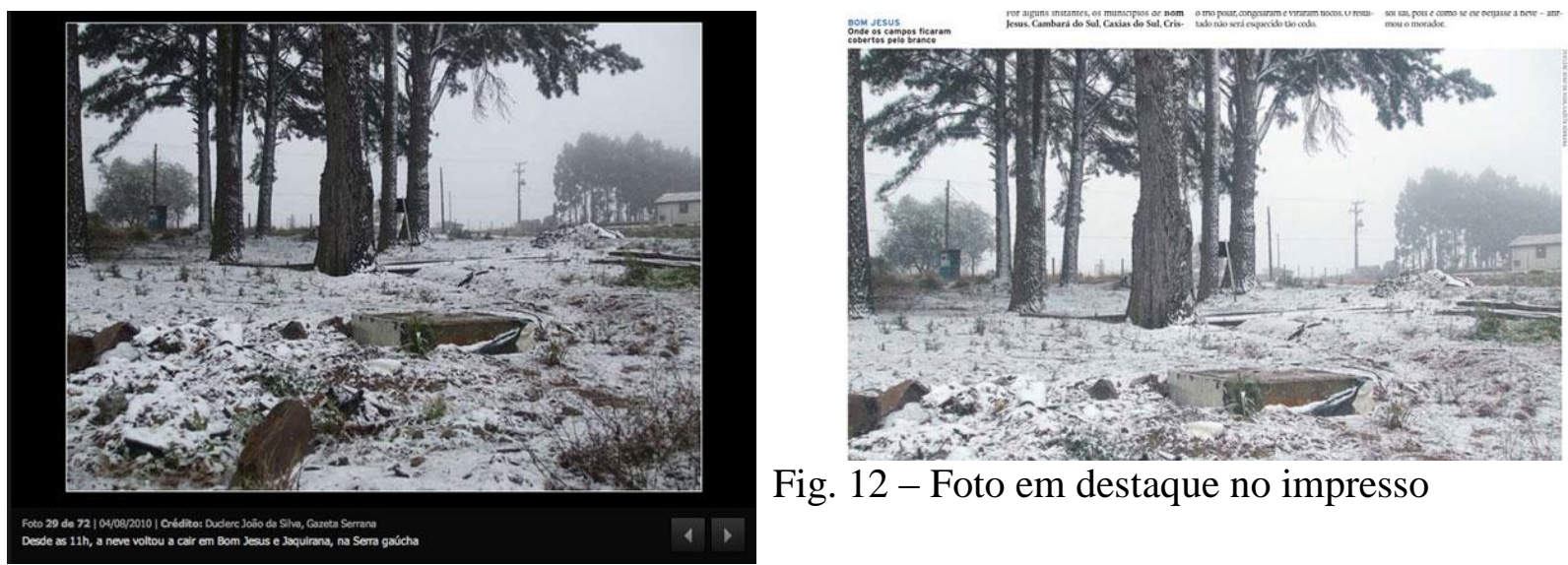

Fig. 12 - Foto em destaque no impresso

Fig. 11 - Foto publicada em slideshow online 

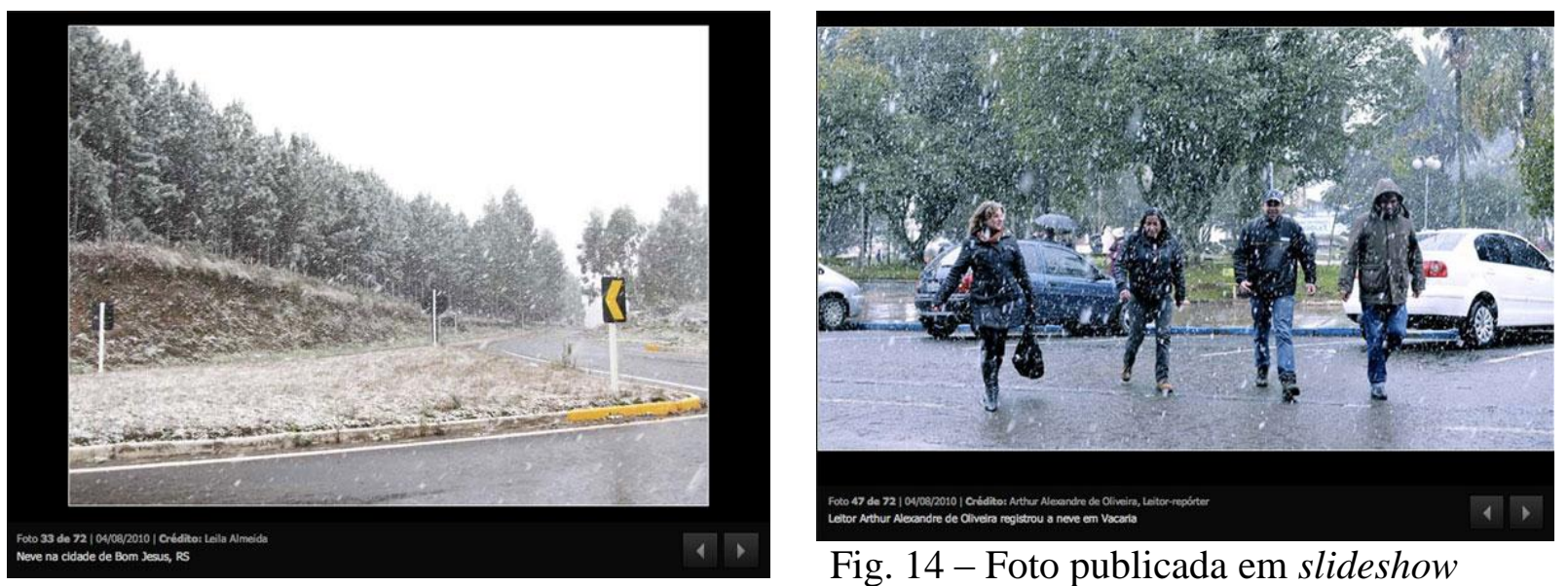

Fig. 14 - Foto publicada em slideshow

Fig. 13 - Foto publicada em slideshow online, produzida por um leitor-repórter online
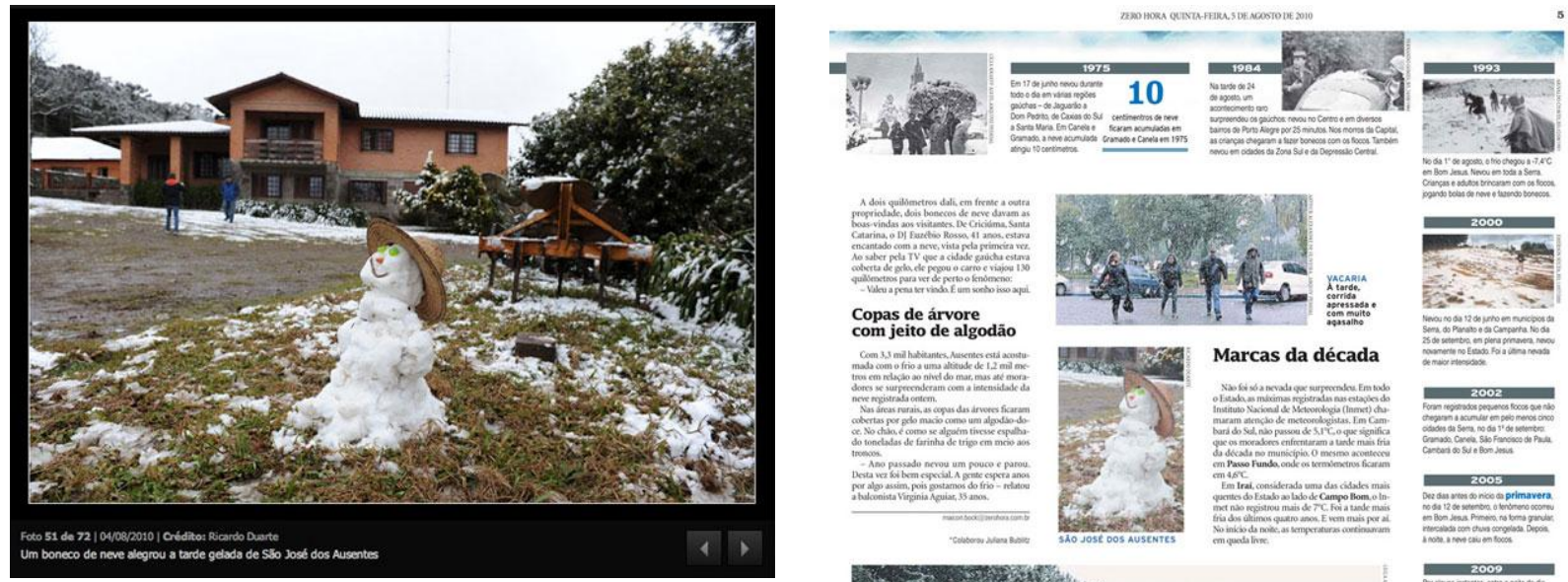

Copas de árvore
com jeito de algodāo

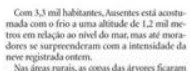

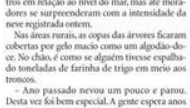

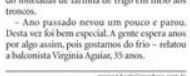

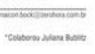
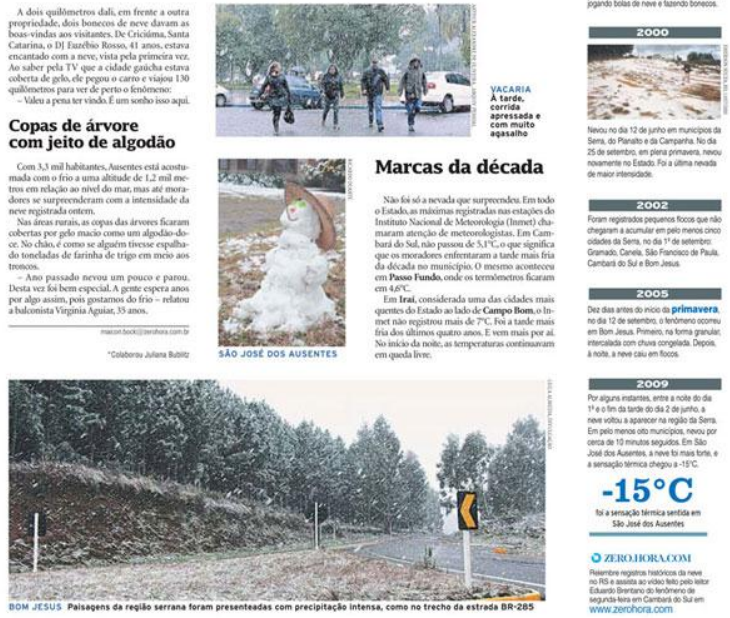

Marcas da década
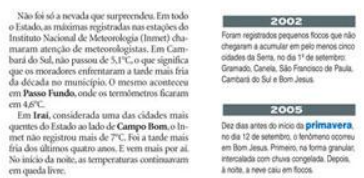

Fig. 15 - Foto publicada em slideshow online

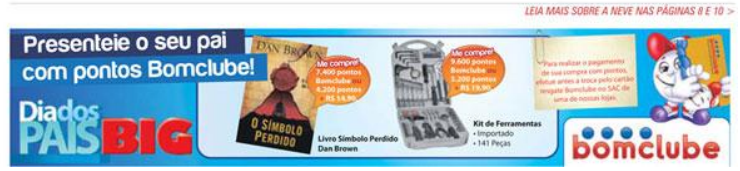

Fig. 16 - fotos replicadas na versão impressa

Os temas abordados em 4 e 5 de agosto de 2010 se repetem (neve no Sul do país), o que permite uma análise dos dados desses dois dias juntos, constatando-se que, no total, das 1.180 fotografias utilizadas, apenas $71(6,02 \%)$ são diferentes entre si. Destas, 5 (7,04\%) foram utilizadas também no impresso (Tab. 4). 


\begin{tabular}{|c|c|}
\hline \multirow{2}{*}{\multicolumn{2}{|c|}{$\begin{array}{l}\text { Matéria I-A e B } \\
\text { Total de matérias online }\end{array}$}} \\
\hline & 30 \\
\hline Total de matérias com foto ................ & 29 \\
\hline & 1 \\
\hline 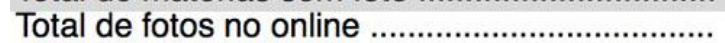 & 1.180 \\
\hline Total de fotos originais & 71 \\
\hline & \\
\hline
\end{tabular}

Tab. 4 - Dados em 4 e 5 de agosto

Um dado instigante acerca deste material dos dias 4 e 5 de agosto é que 34 das 71 fotografias $(47,89 \%)$ originais do online são creditadas a leitores-repórteres. As câmeras digitais que se popularizaram nos anos 1990 vieram facilitando a produção e circulação de imagens, e nos anos 2000, com a proliferação de celulares com câmeras digitais e o acesso expandido à Internet banda larga, vimos a expansão do que se vem denominando jornalismo participativo, baseado na web $2.0^{16}$. A produção proveniente de "cidadão comuns" encontra espaço na rede não apenas em canais específicos para este tipo de conteúdo, mas também em espaços editoriais de empresas jornalísticas, como é o caso da RBS. Mais do que isto, ganham as páginas do veículo impresso.

Como vimos acima, na edição impressa do dia 5 (Fig. 17), a terceira foto de baixo para cima está creditada como "fulano/arquivo pessoal", enquanto que no online a mesma imagem aparece como "fulano/leitor-repórter". Além disso, no dia 4, outras três fotografias do impresso são identificadas como "fulano/arquivo pessoal", não ficando claro se foram ou não produzidas por colaboradores (Fig. 1 - foto menor da pág. 4 e Fig. 17). A composição destas três imagens e os textos que as acompanham, no entanto, indicam que sim. Um homem e dois meninos, respectivamente, posam para a câmera. No primeiro caso, a legenda informa: "Rodolfo foi fotografado pela mãe, Alba, comemorando os flocos"; no segundo, lemos: "Lucas foi até o carro do pai para deixar registrada sua marca”, o que, juntamente com as informações do texto, também deixa indícios de que a produção da foto foi caseira. No terceiro caso, o texto deixa clara a autoria da foto: "Feliz, o guri abriu os braços para cliques fotográficos da mãe”. Considerando-

\footnotetext{
${ }^{16}$ De acordo com Primo (2006), a web 2.0 refere-se à segunda geração de serviços online e caracteriza-se por potencializar as formas de publicação, compartilhamento e organização de informações, além de ampliar os espaços para a interação entre os participantes do processo, potencializando o trabalho coletivo, de troca afetiva, de produção e circulação de informações, de construção social e de conhecimento apoiada pela informática. $\mathrm{O}$ autor frisa que ela diz respeito não apenas a uma combinação de técnicas informáticas (serviços Web, linguagem Ajax, Web syndication, etc), mas também a um determinado período tecnológico, a um conjunto de novas estratégias mercadológicas e a processos de comunicação mediados pelo computador. A disponibilidade dessas condições faz surgir novas práticas em rede, como o webjornalismo participativo.
} 
se, ainda, que a neve é um fenômeno que exige registro rápido, pois pode dissipar-se, temos mais um indício de que a segunda foto também tenha sido um flagra registrado pela família do garoto.

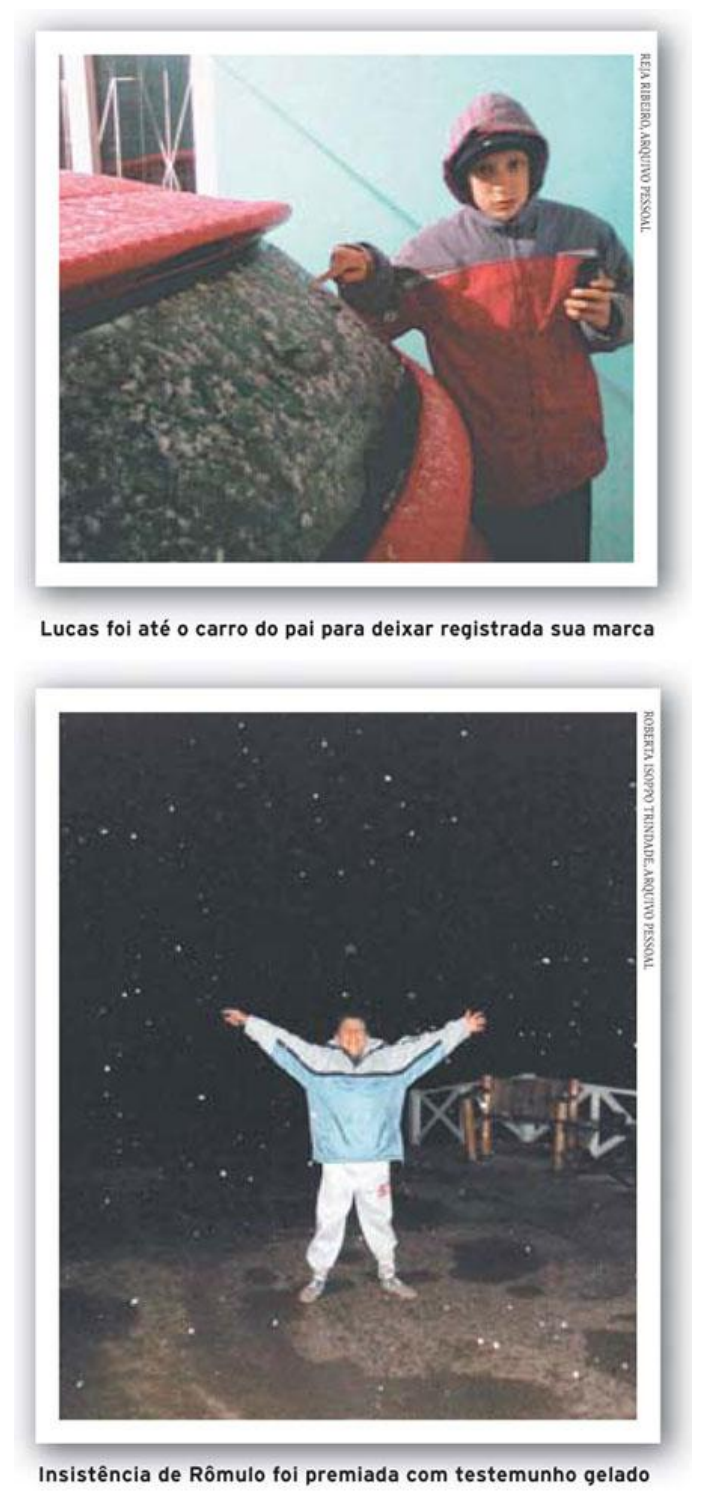

Fig. 17 - Crédito das fotos não deixa claro se foram produzidas por leitores-repórteres

Supondo, portanto, que quatro das 13 fotos publicadas no impresso nos dias 4 e 5 são de autoria de leitores-repórteres, poderíamos justificar a ocorrência com dois fatores, essencialmente. Primeiro, a natureza da pauta. Trata-se de um tema leve, cotidiano, excepcional (a neve era inédita até então em 2010 e há anos não ocorria com tanta intensidade, segundo 
informações trazidas pela Zero Hora e pelo site zerohora.com) - e que estimula a participação dos "cidadãos comuns" na produção de conteúdo. Segundo, a facilidade de acesso da população às tecnologias, o que potencializa a participação no processo produtivo, como apontam Palácios e Munhoz (2007, p.63):

Os efeitos da participação do cidadão na produção de imagens com valor jornalístico são detectáveis tanto no que se refere à criação e consolidação de circuitos alternativos de circulação de informação, quanto no que diz respeito às transformações da mídia tradicional em sua convivência forçada com os novos circuitos.

Contudo, é instigante o fato de que, no online, há clareza quando a autoria das fotos produzidas por leitores-repórteres; já no impresso, quando há colaboração, esta fica mascarada com créditos como "fulano/arquivo pessoal". Nesse sentido, "o jornalismo cidadão abre uma nova e dinâmica fonte de informação. A grande mídia, ao mesmo tempo em que busca preservar seus espaços de funcionamento e hegemonia, vê-se forçada a estabelecer simbioses com os novos circuitos de informação.” (PALÁCIOS; MUNHOZ, 2007, p.77)

Em 9 de agosto (I-C) foram publicadas seis matérias sobre o tema na plataforma digital (Tab. 5). O material impresso apresentou seis fotografias (Figs. 18 e 19) e o online 49 - contudo, apenas dez são diferentes entre si (20,41\%). Ao comparar as fotografias nos dois suportes, observamos seis imagens em comum. Muitos destes dados se justificam porque esta era uma pauta investigativa, realizada por uma equipe de reportagem da RBS TV, e publicada na Zero Hora com seis fotos (as quais foram reproduzidas posteriormente em todas as matérias do online, com acesso por meio de links). Das quatro fotos usadas apenas no online, três aparecem ilustrando matérias (Figs. 21 e 22) e uma está na galeria, podendo ser acessada apenas por um link (Fig. 20). Este fator indica a tentativa de dar destaque às imagens novas, que provavelmente surgiram na sequência das investigações.

\begin{tabular}{|c|c|}
\hline Matéria I-C & \\
\hline Total de matérias online ........................................ & 6 \\
\hline Total de matérias com foto ..................................... & 6 \\
\hline 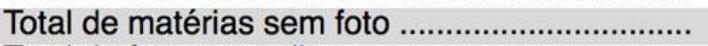 & 0 \\
\hline Total de fotos no online ....................................... & 49 \\
\hline 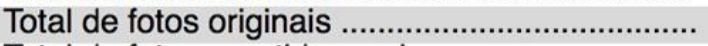 & 10 \\
\hline Total de fotos repetidas no impresso .................. & 6 \\
\hline
\end{tabular}

Tab. 5 - Dados em 9 de agosto 


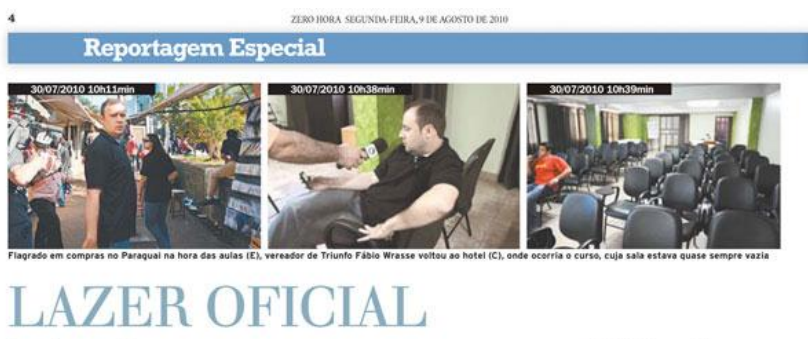

\section{Turismo pago com diárias}

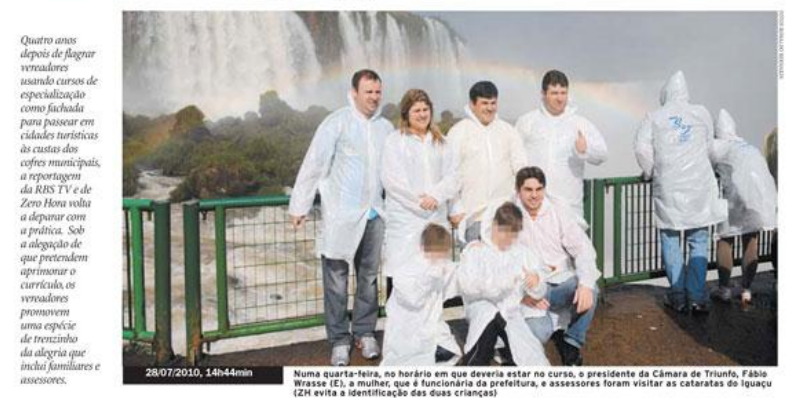

Fig. 18 - Fotos do impresso foram replicadas no online

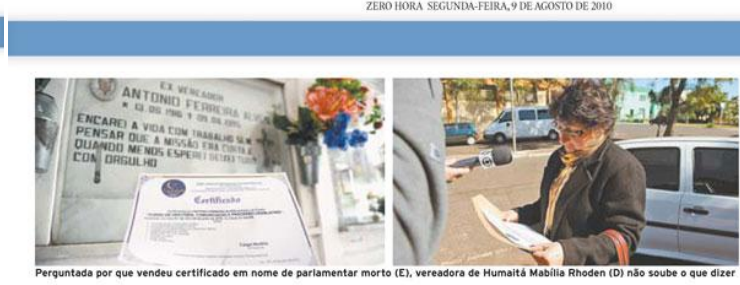

Fig. 19 - Fotos do impresso foram replicadas no online

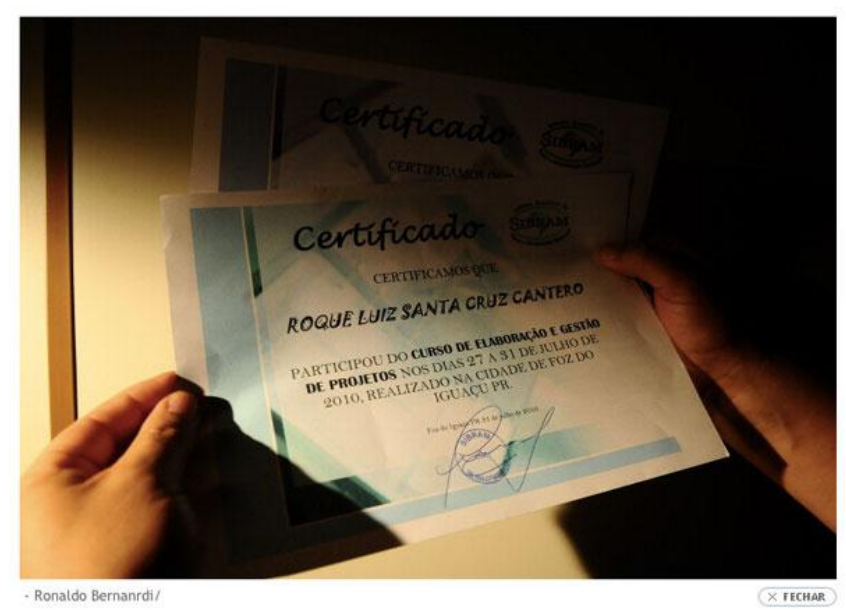

Fig. 20 - Foto usada apenas no online

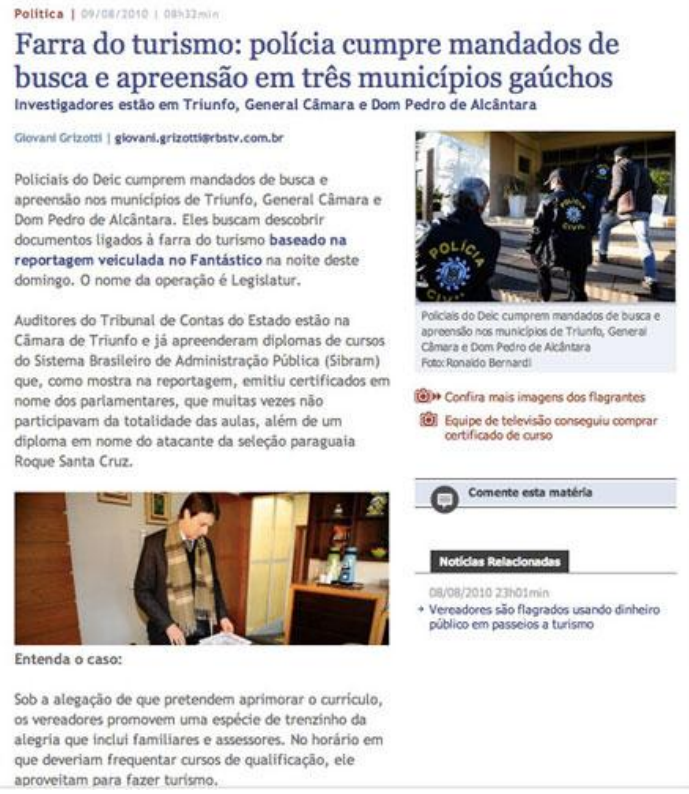

Fig. 21 - Fotos usadas apenas no online
Presidente da Câmara de Vereadores de Triunfo (RS) se licencia após denuncia das diárias cargo foi repassado para o vice, Jaso Batista dos Reis Cunha (PDT)
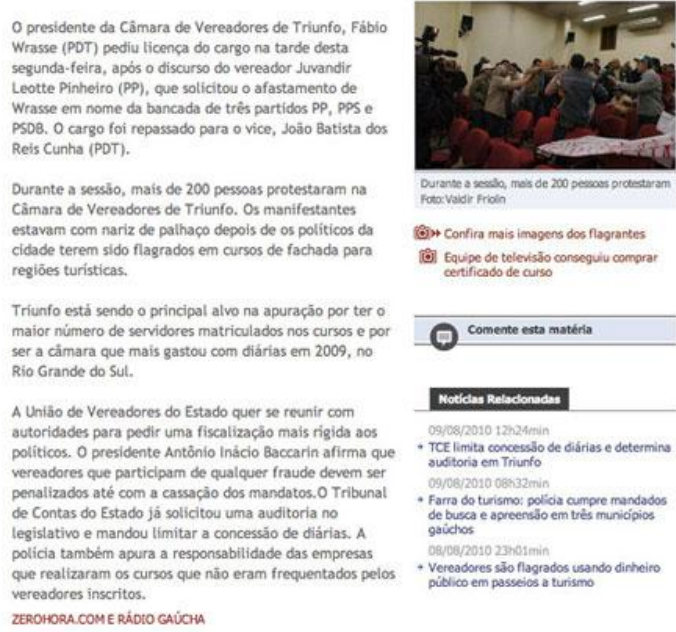

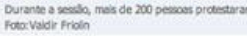
(6). Corfira mais imagens dos flagrantes

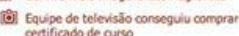
Q. Comente esta materia

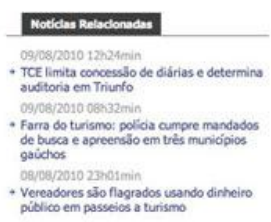

Fig. 22 - Foto usada apenas no online 
Já no dia 18 de agosto foram veiculadas no online 28 matérias sobre o tema abordado no impresso (I-D). A Zero Hora publicou 14 fotografias e o site zerohora.com 18 - destas, apenas uma repetiu-se (portanto, 94,44\% das fotos deste dia são diferentes entre si). Não identificamos nenhuma imagem em comum no impresso e no online (Tab. 6).

\begin{tabular}{|c|c|}
\hline Matéria I - D & \\
\hline Total de matérias online ................................... & 28 \\
\hline Total de matérias com foto & 18 \\
\hline Total de matérias sem foto ..................................... & 10 \\
\hline 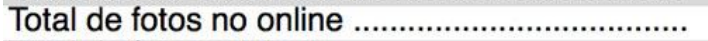 & 18 \\
\hline 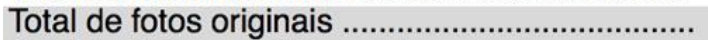 & 17 \\
\hline Total de fotos repetidas no impresso .................. & 0 \\
\hline
\end{tabular}

Tab. 6 - Dados em 18 de agosto

No último dia de análise (I-E) foi registrada a maior produção dentre as pautas analisadas - 42 matérias publicadas no site zerohora.com (Tab. 7). O jogo final da Libertadores da América (Inter x Chivas), ocorrido na noite anterior, interessava a um público amplo - não apenas torcedores do time gaúcho, mas, por ser um evento internacional, do qual participaram outros clubes brasileiros e estrangeiros, atraiu olhares dos mais diversos recantos. Isso justifica a grande repercussão e a quantidade de imagens veiculadas no dia 19 de agosto - o mais expressivo da análise, nas duas plataformas. O material impresso apresentou dez fotografias e o online 1.633 das quais 75 diferentes $(4,59 \%)$. Como dito anteriormente, o número total se deve à repetição de links nas matérias remetendo sempre aos mesmos slideshows e galerias de imagens. Uma comparação das fotografias nos dois suportes indica uma imagem em comum (Figs. 23 e 24).

\begin{tabular}{|c|c|}
\hline Matéria I - E & \\
\hline Total de matérias online .................................... & 42 \\
\hline 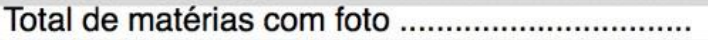 & 40 \\
\hline Total de matérias sem foto ............................ & 2 \\
\hline 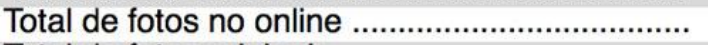 & 1.633 \\
\hline 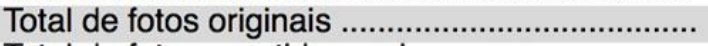 & 75 \\
\hline Total de fotos repetidas no impresso .................. & 2 \\
\hline
\end{tabular}

Tab. 7 - Dados em 19 de agosto 


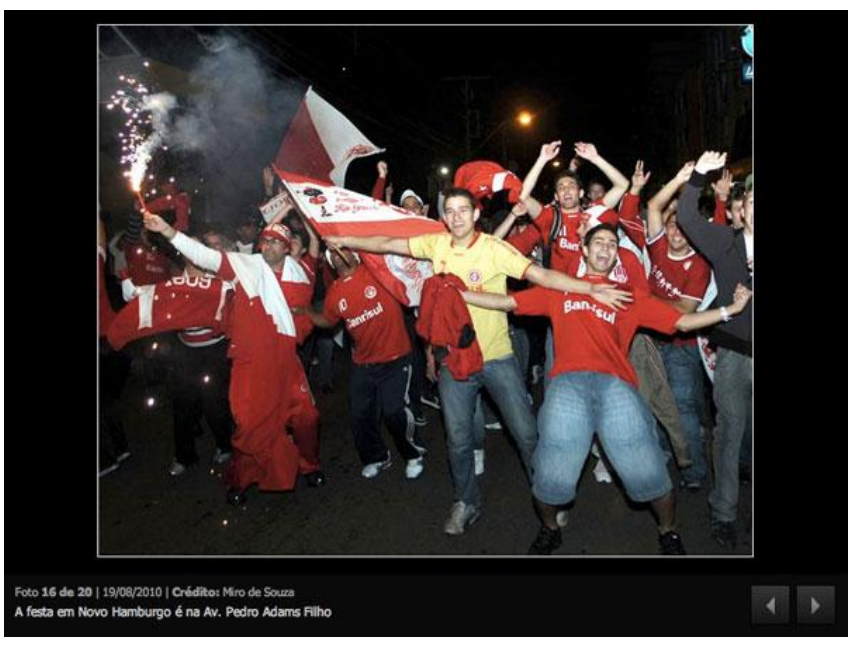

Fig. 23 - foto publicada em slideshow online

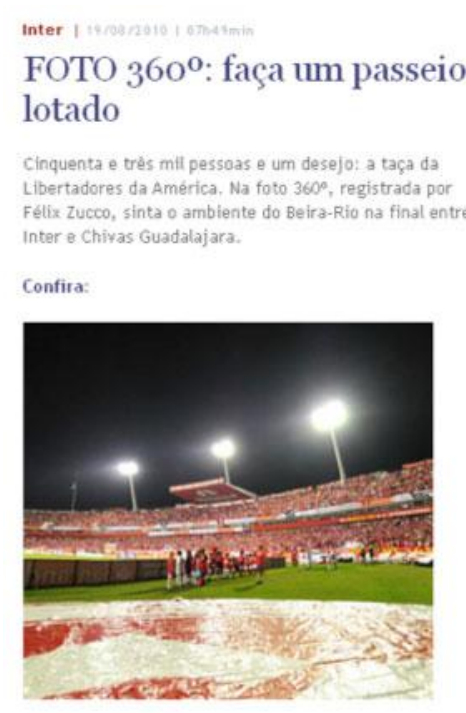

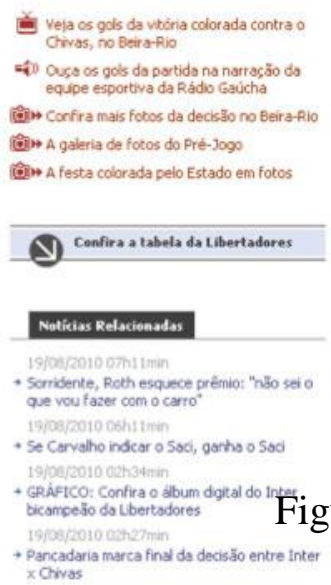

Fig
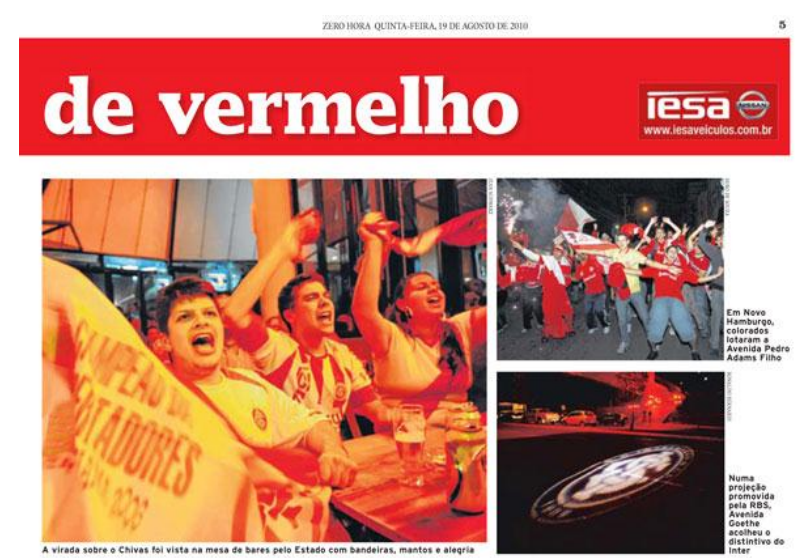

Fig. 24 - foto publicada no impresso (canto superior direito)

Fig. 25 - foto $360^{\circ}$ : em flash e com áudio

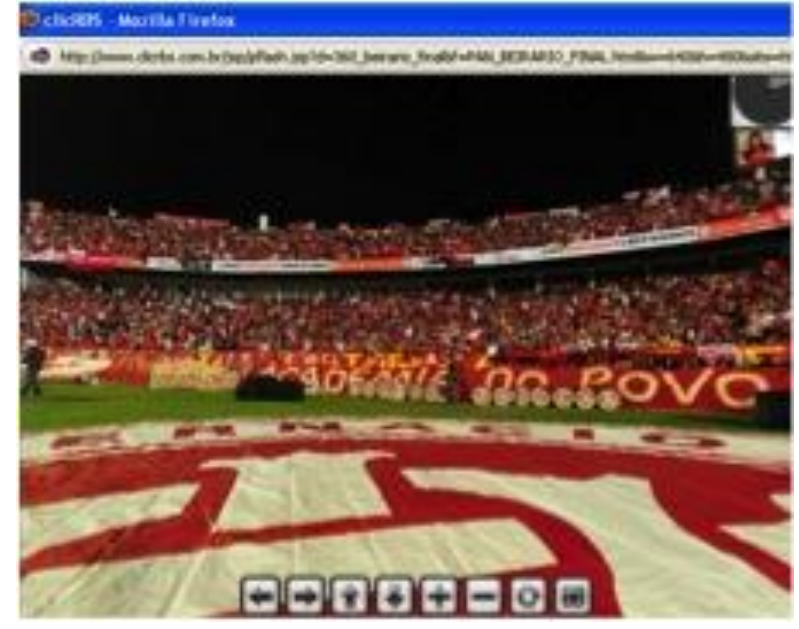

permitem interação com foto $360^{\circ}$

Ainda em 19 de agosto, o site zerohora.com publicou uma foto $360^{\circ}$ do estádio lotado na final do campeonato (Figs. 25 e 26). Utilizando Flash ${ }^{17}$, a imagem ganhou movimento e áudio. Além disso, por meio de botões, o internauta pode interagir com a imagem: movimentá-la para cima, para baixo, definir diferentes angulações, dar zoom in/zoom out, ampliar para tela cheia no computador (Fig. 26) - possibilidades estas características da terceira geração do webjornalismo.

\footnotetext{
${ }^{17}$ O Adobe Flash (mais conhecido por Flash, simplesmente) é um software utilizado para a criação de animações que funcionam por meio de um navegador Web (como o Internet Explorer ou o Mozilla Firefox, por exemplo). Suas últimas versões têm recursos multimídia, possibilitando execução de imagem, som e interatividade.
} 
A vitória do Internacional acarretou mudanças no layout das páginas 4 e 5 da Zero Hora

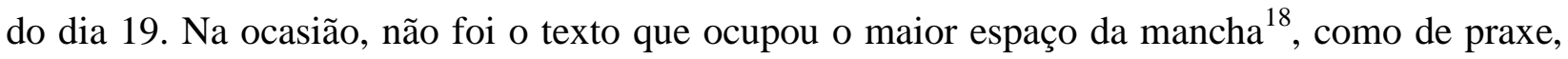
mas sim as fotografias. O texto resumiu-se a um parágrafo e às legendas das dez imagens publicadas. Como vimos, neste caso, a função estética das fotografias predominou sobre a função informativa. Já na plataforma digital, apesar da relevância, o evento não causou mudanças na forma de apresentação das fotografias.

Nos dias 18 e 19 de agosto de 2010 o tema das matérias analisadas foi a final do campeonato Libertadores da América (jogo entre Internacional e Chivas). Unindo os dados dessas duas datas, constata-se que, das 1.651 fotografias publicadas nestes dois dias, 92 (5,57\%) são diferentes e, deste total, duas $(1,17 \%)$ foram utilizadas também no jornal impresso (Tabs. 8 e 9). Neste caso, apenas uma foto está creditada como "arquivo pessoal”, mas não há como saber se foi cedida por um leitor-repórter.

\begin{tabular}{|c|c|}
\hline \multirow{2}{*}{$\begin{array}{l}\text { Matéria I - D e E } \\
\text { Total de matérias online }\end{array}$} & \\
\hline & 70 \\
\hline Total de matérias com foto & \\
\hline Total de matérias sem foto ................................ & \\
\hline Total de fotos no onlir & 1.651 \\
\hline Total de fotos orig & \\
\hline otal de fotos rep & \\
\hline
\end{tabular}

Tab. 8 - Dados em 18 e 19 de agosto

Para que o objetivo deste trabalho seja contemplado é importante voltarmos o olhar ao número de fotografias que foram publicadas tanto no impresso quanto no online:

\begin{tabular}{|c|c|c|}
\hline & Fotos em comum & $\%$ \\
\hline Matéria I-A & 1 & 1,28 \\
\hline Matéria I-B & 4 & 7,02 \\
\hline Matéria I-C & 6 & 60 \\
\hline Matéria I-D & 0 & 0 \\
\hline Matéria I-E & 2 & 2,67 \\
\hline
\end{tabular}

Tab. 9 - Fotos repetidas no impresso e no online

Observamos que, das 217 fotos diferentes veiculadas nos cinco dias de análise, apenas 13 (6\%) foram publicadas também na versão impressa, evidenciando a diversidade no material

\footnotetext{
${ }^{18}$ Mancha é o espaço delimitado em cada página para impressão.
} 
fotográfico conforme muda o suporte. A porcentagem de fotos repetidas nas duas plataformas sobe na matéria I - C, de 9 de agosto, quando a pauta é investigativa e, portanto, o material fotográfico depende exclusivamente da equipe de reportagem que fez este trabalho (o que justifica a repetição das seis fotos publicadas no impresso em todas as matérias do online). A variação acontece depois da repercussão da primeira matéria publicada sobre o tema, quando a evolução da investigação passa a pautar novas matérias, acarretando, consequentemente, a produção de novas fotos.

Nos dias 4 e 5 de agosto, constatamos que o impresso deu uma chamada para que os leitores acessassem o site zerohora.com para conferirem mais informações sobre o tema em pauta - a neve. A mensagem "Relembre registros históricos da neve no RS e assista ao vídeo feito pelo leitor Eduardo Brentano do fenômeno de segunda-feira em Cambará do Sul em www.zerohora.com", porém, não indica que no site o usuário também poderia ver mais fotos do fato atual - o que provavelmente muitos deles fizeram ao navegar pelas páginas online que tratavam deste assunto, visto que os links para as galerias se repetem em várias ocasiões.

Os dados levantados também denotam que apenas 12\% das 106 matérias analisadas no site zerohora.com não possuem fotos. Portanto, a edição digital tem aproveitado o potencial deste meio, assim como os recursos característicos da atual fase do webjornalismo, cujo exemplo mais expressivo nesta análise são os links para materiais fotográficos já publicados e, provavelmente, armazenados em bancos de dados. Por este motivo, o número total de imagens publicadas a cada dia contrasta com o número de fotos diferentes (ou originais, no sentido de "não repetidas"). $\mathrm{O}$ uso de slideshows e de galerias de fotos também é recorrente - por isso várias matérias possuem exatamente o mesmo número de fotografias - e reforça duas características da quarta geração de desenvolvimento do webjornalismo: o uso de banco de dados e a inserção de materiais produzidos por leitores-repórteres (o que pode ser confirmado pelo crédito das fotos).

Conforme Barbosa (2007), o webjornalismo praticado em bases de dados passa a desempenhar funções específicas relacionadas à gestão interna dos produtos, forma, estruturação e composição das informações, recuperação e apresentação dos conteúdos. Dentre os aspectos destacados pela autora, podemos inferir que em zerohora.com temos a indexação e classificação de peças informativas e dos objetos multimídia; a integração de processos de apuração, composição e edição dos conteúdos; bem como a conformação de padrões novos para a 
construção de peças informativas. Por meio do material fotográfico publicado, identificamos o estoque do material produzido e preservação dos arquivos (memória) assegurando o processo de recuperação das informações; a permissão de uso e concepções diferenciadas para o material de arquivo; e a flexibilização combinatória e o relacionamento entre os conteúdos.

Neste breve trabalho, nossa atenção voltou-se para a autoria das fotografias e o lugar de sua inserção na narrativa jornalística, com o propósito de avaliar a produção e apropriação das imagens nas edições em papel e digital, dentro dos limites de um estudo exploratório. Entendemos que tais aspectos priorizaram a análise de como as características dos dispositivos e os protocolos a eles associados contribuem para a construção de sentido, sem nos determos na consideração dos vários elementos informativos que compuseram cada matéria. O olhar panorâmico permitiu que pudéssemos perceber a presença da contribuição dos "leitoresrepórteres" tanto no impresso como no online, sobretudo na cobertura de temas de caráter menos investigativo; e evidenciou as distinções entre a inserção de fotos no espaço gráfico disponível em simultaneidade do impresso e aquele que se constrói em distintas dimensões por meio links.

Vimos que, se por um lado, a contribuição dos cidadãos nas edições para a web são incentivadas e creditadas como "leitor-repórter", de outro, no impresso, algumas foram utilizadas mediante a indicação de "arquivo pessoal" e, outras vezes, deixando em dúvida qual a forma de vinculação do autor da imagem com o jornal. Isso está associado às modificações nas rotinas de produção jornalísticas discutidas anteriormente, que reiteram que o valor da fotografia na narrativa não está apenas nos conteúdos a que ela remete por meio de sua composição, mas também através do lugar que ocupa no conjunto da reportagem ligado a cada dispositivo.

Conforme Buitoni (2011, p.155), "a imagem representada, isto é, inscrita em um suporte de veiculação, está diretamente relacionada aos conceitos representativos que são próprios daquele suporte". Podemos associar esta afirmação tanto ao aspecto anterior, como às dimensões espaciais e temporais que perpassam os distintos suportes das edições. O impresso, delimitado por um formato e um prazo de fechamento da edição, exige a seleção de momentos pregnantes, que passam pela seleção das fotografias mais representativas do acontecimento, segundo critérios vinculados ao campo jornalístico. Estas imagens, por sua vez, serão hierarquizadas pelo layout da página, vinculadas aos diferentes estilos de texto. No online, observamos a presença de uma imagem destacada ao lado do texto e a opção sobretudo por links que remetiam a slideshows em 
que a quantidade parece preponderar. Diante do volume de informações que passam a conformar os bancos de dados e que são produzidas não apenas de jornalistas profissionais, mas também por inúmeros colaboradores, observamos a "incapacidade de dar forma jornalística acabada a todo esse material que se faz disponível, fornecendo um contexto interpretativo a essa poeira informativa produzida em primeira pessoa, de maneira que ela venha a adquirir significado e se torne conhecimento" (SOFI ${ }^{19}$, 2006, apud PALÁCIOS; MUNHOZ, 2007, p.77). Os diferentes desdobramentos online das reportagens impressas, bem como a quantidade e modos de utilização das fotografias demonstraram a interligação entre a cobertura, assim como a singularidade de cada edição relacionada a reestruturação da produção jornalística no âmbito das rotinas e das novas possibilidades de geração, publicação e circulação de conteúdo.

\section{CONSIDERAÇÕES FINAIS}

O tratarmos de padrões contemporâneos de jornalismo, analisando especificamente a fotografia em Zero Hora e zerohora.com, constatamos que as modificações no sistema de mídia compreendem intercâmbios diversos entre a mídia tradicional impressa e aquela online, a exemplo do que ocorreu nos dias 4 e 5 de agosto, com a publicação de fotos produzidas por leitores-repórteres no veículo impresso. Se, num primeiro momento, a produção colaborativa encontrava espaço apenas em locais devidamente identificados como tal, agora vemos sua inserção junto ao conteúdo editorial desenvolvido por jornalistas profissionais. Contudo, este movimento ainda é tímido. Ao migrar para o impresso, nenhuma das quatro fotografias enviadas por leitores-repórteres foi creditada com esta informação, de modo que só foi possível diagnosticá-las ao lermos o texto das matérias e, em um dos casos, ao conferirmos o crédito da foto na versão online.

O expressivo número de fotografias usadas apenas na plataforma digital (não replicadas no impresso) permite-nos afirmar que o site zerohora.com fornece aos internautas um conteúdo diferenciado, com informações complementares ao leitor de Zero Hora. Além disso, a dinamicidade e as possibilidades de interação (seja nos slideshows, nos links ou na foto $360^{\circ}$

\footnotetext{
${ }^{19}$ SOFI, Antonio. Um nuovo giornalismo s'íntreccia nella Rete: l'informazione nell'era dei blog, in: SORRENTINO, Carlo (Org), Il Campo Giornalistico: i nuovi orizzonti dell‘informazione, Carocci Editore, Roma, 2006.
} 
publicada no dia 19) também atraem e podem cativar o internauta. Entretanto, o impresso poderia chamar os leitores para consultarem o material online - o que ocorreu apenas nos dias 4 e 5 de agosto, mas não diretamente relacionado às fotos, como observamos na análise.

Diante do que foi analisado, entendemos que as tecnologias digitais proporcionam à mídia tradicional, instituída profissionalmente, um cenário propício para reinventar-se, segundo noções de complementaridade e potencialização. As iniciativas avaliadas revelam mudanças, tensões, ajustes, erros e acertos, que demonstram em um veículo singular experiências editoriais que delineiam modos de reconfiguração de processos e produto jornalísticos. Como assinala Jenkins (2008), a convergência digital está afetando o relacionamento entre indústrias, mercados e audiências, é uma mudança de paradigma que vem alterando a lógica com que os meios operam.

Deste estudo exploratório surgem dúvidas e problematizações para fomentar ainda mais as pesquisas sobre o tema. Questões como a qualidade estética e/ou informativa, por exemplo, devem ser analisadas neste cenário em que a quantidade de imagens é exacerbada. A intenção, neste momento, foi apontar elementos que possam colaborar para a construção do conhecimento acerca deste contexto digital, tecnológico, interconectado, colaborativo, desterritorializado e descentralizado no qual se pratica o jornalismo contemporâneo.

\section{REFERÊNCIAS}

BARBOSA, S. Banco de Dados como metáfora para o jornalismo digital de terceira geração. In: Ciências da Comunicação em Congresso na Covilhã. III Sopcom, VI Lusocom, II Ibérico, UBI (CDROM), 2004.

BARBOSA, S. Jornalismo Digital em Base de Dados (JDBD): um paradigma para produtos jornalísticos digitais dinâmicos. Tese de Doutorado. Programa de Pós-Graduação em Comunicação e Culturas Contemporâneas. FACOM/UFBA, Bahia, 2007.

BARDIN, L. Análise de conteúdo. Tradução de Luís Antero Reto e Augusto Pinheiro. Lisboa: Edições 70, 1977.

BUITONI, D. S. Fotografia e jornalismo: a informação pela imagem. São Paulo: Saraiva, 2011. 
CANAVILHAS, J. M. Considerações gerais sobre jornalismo na web. 2001. Disponível em: <http://www.bocc.ubi.pt/pag/canavilhas-joao-webjornal.html>. Acesso em: 28 jul. 2010.

FONSECA, V. P.S. Indústria de Notícias: capitalismo e novas tecnologias no jornalismo contemporâneo. Porto Alegre: Editora da UFRGS, 2008.

JENKINS, H. Cultura da convergência. São Paulo: Aleph, 2008.

MACHADO, A. A Fotografia sob o Impacto da Eletrônica. In: SAMAIN, E. (org.). O Fotográfico. São Paulo: Hucitec; Senac, 2005.

MACHADO, E. A Base de Dados como formato no jornalismo digital. Disponível em: <http://www.bocc.ubi.pt/pag/machado-elias-base-dados-formato-jornalismo-digital.pdf> Acesso em: 6 out. 2011.

MACHADO, E. O banco de dados como espaço de composição de narrativas multimídia. 2004. Anais do II SBPJOR. Novembro de 2004. Salvador. Brasil. CD.

MACHADO, E.; PALACIOS, M.; SCHWINGEL, C.; ROCHA, L. Plataforma Panopticon: um jornal laboratório, multi-usuário e descentralizado. In: MACHADO, E.; PALÁCIOS, M. (org). $O$ Ensino do jornalismo em redes de alta velocidade: metodologias \& software. Salvador: EDUFBA, 2007, pp.111-128.

MIELNICZUK, L. Jornalismo na web: um estudo sobre o formato da notícia na escrita hipertextual. Tese de doutorado. Programa de Pós-Graducação em Comunicação e Cultura Contemporânea da Faculdade de Comunicação da Universidade Federal da Bahia, 2003.

MUNHOZ, P.Estágios de desenvolvimento do fotojornalismo na internet. In: Diálogos \& Ciência. Revista da Rede de Ensino FTC. ISSN 1678-0493. Ano V, n. 11, set. 2007.

PALACIOS, M. Jornalismo Online, Informação e Memória: Apontamentos para debate. Comunicação apresentada nas Jornadas de Jornalismo Online, Universidade da Beira Interior (Portugal), 2002.

PALACIOS, M.; MUNHOZ, P.Fotografia, Blogs e Jornalismo na Internet: Oposições, Apropriações e Simbioses. In: BARBOSA, S. (org.). Jornalismo digital de terceira geração. Labcom - Universidade da Beira Interior. Covilhã, 2007. Disponível em: 
http://www.livroslabcom.ubi.pt/pdfs/20110824-

barbosa_suzana_jornalismo_digital_terceira_geracao.pdf p.63-84.

PAVLIK, J. V. Journalism and new media. New York: Columbia University Press, 2001.

PRIMO, A. O aspecto relacional das interações na Web 2.0. Anais do XXIX Congresso Brasileiro de Ciências da Comunicação - Intercom. Universidade de Brasília (Unb). Brasília, 2006.

ROUILLÉ, André. A Fotografia: entre documento e arte contemporânea. São Paulo: Senac, 2009.

SANTAELLA, L. Por uma epistemologia das imagens tecnológicas: seus modos de apresentar, indicar e representar a realidade. In: ARAUJO, Denize Correa (org.). Imagem (ir)realidade: comunicação e cibermídia. Porto Alegre: Sulina, 2006.

SILVA Jr., J. A.; QUEIROGA, E. Fotojornalismo colaborativo em tempos de convergência. Brazilian Journalism Research, vol.6, n. 2, 2010.

SOUSA, J. P.Fotojornalismo: uma introdução à história, às técnicas e à linguagem da fotografia na imprensa. Porto, 2002. Disponível em: <http://pt.scribd.com/doc/504735/fotojornalismo-umaintroducao-a-historia-as-tecnicas-e-a-linguagem-da-fotografia-na-imprensa\#touter_page_78> Acesso em 20 jun. 2011.

SOUSA, J. P.Uma história crítica do fotojornalismo ocidental. Chapecó: Argos; Florianópolis: Letras Contemporâneas, 2004.

STRELOW, A.; GRUSZYNSKI, A.; NECCHI, V. Backup do jornalismo digital. In: PRIMO, A. Mapeamento 2: do ensino de jornalismo digital no Brasil em 2010. São Paulo: Itaú, 2010.

VAZ, P.(org.) Narrativas fotográficas. Belo Horizonte: Autêntica, 2006.

Original recebido em: 15/11/2011

Aceito para publicação em: 29/11/2011

Resumo sobre as autoras

Ana Gruszynski

Formada em jornalismo pela Universidade

ANIMUS R. Interamericana de Comunicação Midiática, http://www.ufsm.br/revistas E-ISSN 2175-4977, v. 10, n. 20, 2011 
Federal do Rio Grande do Sul (UFRGS), com mestrado e doutorado em

Comunicação pela Pontifícia Universidade Católica do Rio Grande do Sul. Designer.

Professora do Programa de Pós-Graduação em Comunicação e Informação da

Universidade Federal do Rio

Grande do Sul. Pesquisadora do Conselho

Nacional de Desenvolvimento Científico e

Tecnológico (CNPq). Currículo Lattes:

http://lattes.cnpq.br/7551841120248747

Cristiane Lindemann

Formada em jornalismo pela Universidade de Santa Cruz do Sul (UNISC). Mestre pelo

Programa de Pós-Graduação em

Comunicação e Informação da

Universidade Federal do Rio

Grande do Sul. Doutoranda no

PPGCOM/UFRGS. Bolsista Coordenação

de Aperfeiçoamento de Pessoal de Nível

Superior (Capes). Currículo Lattes:

http://lattes.cnpq.br/5354378462271850 